\title{
Carpal tunnel syndrome in early rheumatoid arthritis
}

\author{
M. ANNE CHAMBERLAIN AND MARY CORBETT \\ From Arthur Stanley House, The Middlesex Hospital, London, W.1
}

It is a commonly held idea that a transient carpal tunnel syndrome often heralds the onset of rheumatoid arthritis (Copeman, 1968) and is frequently present in the early stages of the disease (Brewerton, 1965). There is relatively little in the literature, however, about the prevalence of the syndrome in the early stages of rheumatoid arthritis. Barnes and Currey (1967) found that five of fifteen patients who had suffered from the disease for less than 2 years had abnormal electrodiagnostic tests, and Polley and Lipscomb (1966) reported that 100 of a series of 1,215 patients with the carpal tunnel syndrome had co-existent rheumatoid disease, and that in 38 of these the signs and symptoms appeared simultaneously.

Compression neuropathy, as Pallis and Scott (1965) have shown, is not the only neurological complication of rheumatoid disease. Mononeuritis multiplex, a distal sensory neuropathy, and a sensorimotor type of lesion have also been observed.

For these reasons, an electrodiagnostic study was undertaken in 36 patients with rheumatoid arthritis.

\section{Material}

A long-term prospective study of the clinical, immunological, and radiological features of early rheumatoid disease is being made at Arthur Stanley House. At the time when the present study was carried out 72 patients were taking part in the series. Criteria for entry were that the patient must have had the disease for less than a year and that he should be willing and able to attend a special electrodiagnostic research clinic at 4-monthly intervals. This latter criterion presupposed some selfselection, as did the further agreement by some patients to undergo ophthalmological and dermatological examinations and nerve conduction studies.

Some patients, because of commitments in the home or at work, were unwilling to give up their time to attend for these special studies, but 36 of the 72 patients consented to attend for electromyography. Clinically those who attended and those who did not were fairly well matched (see Table I), and their ages were similar (19 to 75 years).

\section{Method}

The hand was warmed where necessary; the skin temperature was at least $28^{\circ} \mathrm{C}$.

A concentric needle electrode was inserted into the abductor pollicis brevis muscle of the dominant hand. The interference pattern, the presence or absence of fibrillation, and the insertion activity were noted. Single brief supramaximal shocks were then delivered over the median nerve at the wrist and at the elbow. The distal latency from the wrist and the motor conduction velocity in the forearm were calculated from the photographic record so obtained.

Sensory action potentials were recorded for the median and ulnar nerves at the wrist according to the method of Dawson (1956). In cases in which abnormalities were found, the procedure was, if possible, repeated at a

Table I Classification of 72 patients with rheumatoid arthritis, 36 of whom underwent electrodiagnostic tests, by sex

\begin{tabular}{|c|c|c|c|c|c|c|c|c|}
\hline \multicolumn{2}{|c|}{ Conduction studies } & \multicolumn{4}{|c|}{ Performed (36) } & \multirow{2}{*}{\multicolumn{2}{|c|}{ Not performed (36) }} & \multirow[t]{3}{*}{ Total } \\
\hline & & \multicolumn{2}{|c|}{ Normal (32) } & \multicolumn{2}{|c|}{ Abnormal (4) } & & & \\
\hline \multicolumn{2}{|l|}{$\operatorname{Sex}$} & Male & Female & Male & Female & Male & Female & \\
\hline \multicolumn{2}{|l|}{ No. of cases } & 15 & 17 & 3 & 1 & 11 & 25 & 72 \\
\hline $\begin{array}{l}\text { ARA } \\
\text { Classification }\end{array}$ & $\begin{array}{l}\text { Classical } \\
\text { Definite } \\
\text { Probable } \\
\text { Possible }\end{array}$ & $\begin{array}{l}5 \\
7 \\
2 \\
1\end{array}$ & $\begin{array}{l}8 \\
6 \\
1 \\
2\end{array}$ & $\begin{array}{l}0 \\
2 \\
0 \\
1\end{array}$ & $\begin{array}{l}0 \\
1 \\
0 \\
0\end{array}$ & $\begin{array}{l}5 \\
6 \\
0 \\
0\end{array}$ & $\begin{array}{r}1 \\
12 \\
7 \\
5\end{array}$ & $\begin{array}{r}19 \\
34 \\
10 \\
9\end{array}$ \\
\hline
\end{tabular}


later date and extended to include ulnar nerve motor studies.

\section{Results}

No patient complained spontaneously about symptoms related to the carpal tunnel syndrome, but, on direct questioning, seventeen ( 23 per cent.) of the 72 patients admitted to a history of nocturnal paraesthesiae. All seventeen had a positive Tinel or compression test or more usually both, and all had a mild degree of sensory disturbance in the territory of the median nerve. Three patients showed wasting of the small muscles in the hands but in none was this localized to the abductor pollicis brevis muscle. Concurrently with their clinical carpal tunnel syndrome, eleven of these seventeen patients had clinical wrist involvement manifest by local swelling and limitation of movement. Symptoms and signs of the carpal tunnel syndrome were transient; they appeared within one year of the onset of rheumatoid disease and resolved within 6 to 12 months. Only six of these seventeen patients were included in the 36 who underwent electrodiagnostic tests (Table II). Table II also shows some of the clinical findings in both the tested and the untested groups. The presence of nodules, a high sheep-cell titre, and markedly impaired grip strength was more frequent in the group who volunteered for electrodiagnostic tests, and clinical wrist involvement was about the same in both groups. There were only six patients with clinical signs of the carpal tunnel syndrome in the tested group as compared with eleven in the untested group.

Of the 36 patients who volunteered for electrical testing, 32 had entirely normal results. The other four included only two (both men) with clinical signs of the carpal tunnel syndrome. These four patients had a total of seven minor electrical abnormalities between them (Table III).

Case 2 had electrical findings compatible with the clinical carpal tunnel syndrome. When this resolved after 14 weeks, the distal latency and motor conduction velocity returned to normal.

Case 3 also had clinical signs of the carpal tunnel syndrome, but the only support for this diagnosis was a slightly reduced amplitude of the median sensory action

Table II Clinical findings in 72 patients with rheumatoid arthritis, 36 of whom underwent electrodiagnostic tests

Conduction studies

Performed

\begin{tabular}{l}
\hline Normal \\
\hline 32 \\
\hline $4^{*}$ \\
\hline 8 \\
10 \\
9 \\
18 \\
17
\end{tabular}

Arthritis of dominant wrist

Grip $<150 / 30 \mathrm{~mm}$. $\mathrm{Hg}$

\begin{tabular}{l}
\hline Abnormal \\
\hline 4 \\
\hline $2 \dagger$ \\
\hline 1 \\
0 \\
1 \\
4 \\
4
\end{tabular}

\begin{tabular}{l}
$\frac{\text { Total }}{36}$ \\
\hline 6 \\
\hline 9 \\
10 \\
10 \\
22 \\
21
\end{tabular}

Total

\begin{tabular}{ll}
\hline 36 & $\frac{72}{72}$ \\
\cline { 1 - 1 } 11 & $\frac{17}{13}$ \\
4 & 15 \\
6 & 16 \\
26 & 48 \\
15 & 36
\end{tabular}

- All female † both male

Table III Abnormal electrophysical findings in four out of 36 patients with rheumatoid arthritis; two of the four showed clinical signs of the carpal tunnel syndrome

\begin{tabular}{|c|c|c|c|c|c|c|c|c|c|c|c|}
\hline \multirow[t]{3}{*}{ Case no. } & \multirow[t]{3}{*}{$\operatorname{Sex}$} & \multirow{3}{*}{$\begin{array}{l}\text { Age } \\
\text { (yrs) }\end{array}$} & \multirow{3}{*}{$\begin{array}{l}\text { Clinical } \\
\text { signs of } \\
\text { carpal } \\
\text { tunnel } \\
\text { syndrome }\end{array}$} & \multirow{3}{*}{$\begin{array}{l}\text { Distal } \\
\text { latency } \\
\text { at wrist } \\
\text { (msec.) }\end{array}$} & \multirow{3}{*}{$\begin{array}{l}\text { Motor } \\
\text { conduction } \\
\text { velocity } \\
\text { (m./sec.) }\end{array}$} & \multicolumn{4}{|c|}{ Sensory action potential } & \multirow{3}{*}{$\begin{array}{l}\text { Interval } \\
\text { between } \\
\text { tests } \\
\text { (if seen } \\
\text { twice) }\end{array}$} & \multirow{3}{*}{$\begin{array}{l}\text { Skin } \\
\text { temperature } \\
\left({ }^{\circ} C\right)\end{array}$} \\
\hline & & & & & & \multicolumn{2}{|c|}{ Median nerve } & \multicolumn{2}{|c|}{ Ulnar nerve } & & \\
\hline & & & & & & $\begin{array}{l}\text { Latency } \\
\text { to peak } \\
\text { (msec.) }\end{array}$ & $\begin{array}{l}\text { Potential } \\
\text { size } \\
(\mu V)\end{array}$ & $\begin{array}{l}\text { Latency } \\
\text { to peak } \\
\text { (msec.) }\end{array}$ & $\begin{array}{l}\text { Potential } \\
\text { size } \\
(\mu V)\end{array}$ & & \\
\hline 1 & $\mathbf{M}$ & 67 & Nil & & & & & & 4 & & 31 \\
\hline 2 & $\mathbf{M}$ & 56 & $\stackrel{+}{\text { Nil }}$ & $\begin{array}{l}5 \cdot 4 \\
4 \cdot 2\end{array}$ & $\begin{array}{l}48 \cdot 5 \\
58 \cdot 5\end{array}$ & $4 \cdot 7$ & & & & 14 wks & $\begin{array}{l}32 \\
28\end{array}$ \\
\hline 3 & $\mathbf{M}$ & 73 & + & & & & 8 & & 6 & & 31 \\
\hline 4 & $\mathbf{F}$ & 70 & $\begin{array}{l}\text { Nil } \\
\text { Nil }\end{array}$ & & & $\begin{array}{l}4 \cdot 3 \\
4 \cdot 0\end{array}$ & & & & 10 mths & $\begin{array}{l}30 \\
31\end{array}$ \\
\hline \multicolumn{4}{|c|}{ Normal values* } & 5 & $\begin{array}{l}57 \cdot 2 \\
( \pm 4 \cdot 2)\end{array}$ & $2 \cdot 5-0$ & $9-45$ & $2 \cdot 2-$ & ${ }^{8-}$ & & \\
\hline
\end{tabular}

- Taken from Gilliatt and Sears (1958) and Thomas, Sears, and Gilliatt (1959). 
potential. In addition, the ulnar sensory action potential was smaller than normal.

Case 1 showed a small ulnar sensory action potential, but like Case 4 he has no clinical neurological abnormalities.

The mean motor conduction velocity in the median nerve in the forearm of the 36 tested patients was $58.3 \mathrm{~m} . / \mathrm{sec} . \pm 5.42$ which does not differ significantly from the figure of $57.2 \mathrm{~m} . / \mathrm{sec} . \pm 4.2$ found in the controls reported by Thomas, Sears, and Gilliatt (1959).

\section{Discussion}

Although seventeen (23 per cent.) of 72 patients with early rheumatoid disease had clinical evidence of the carpal tunnel syndrome, the number of electrical abnormalities found in the 36 patients who were tested was low and the abnormalities were minor.

It is known that motor conduction velocity reflects the behaviour of the fastest fibres, and one might postulate that the fastest conducting fibres were not involved either directly or indirectly by rheumatoid disease. The discrepancy between the clincial and electrical findings might also be accounted for by a delay (of up to 2 months) which occurred between the clinical diagnosis and the electrical testing.

Whatever the underlying mechanism of the carpal tunnel syndrome, circumstances suggest that it is related to local wrist involvement in early rheumatoid disease. At the time of clinical diagnosis, eleven of the seventeen patients with median nerve irritation also had soft tissue swelling and limitation of movement. As signs of inflammation in the wrist settled with therapeutic measures such as splintage or even without any local treatment, the carpal tunnel syndrome resolved.

It therefore appears that the frequent clinical finding of a transient carpal tunnel syndrome in patients with early rheumatoid disease is not related to electrodiagnostic features which are themselves transient. We therefore suggest that, in cases of early rheumatoid disease, routine electrophysiological testing serves no practical purpose.

\section{Summary}

Of 72 patients admitted to a prospective study of early rheumatoid arthritis, 36 consented to electrodiagnostic investigation. Seven minor electrical abnormalities were found in four patients, two of whom had clinical evidence of the carpal tunnel syndrome. A further four subjects with a firm clinical diagnosis of carpal tunnel syndrome had normal electrodiagnostic tests.

The incidence of electrodiagnostic abnormalities in the 36 tested was thus 5.5 per cent.; the incidence of carpal tunnel syndrome clinically diagnosed in the 36 who underwent electrical tests was six (17 per cent.), and the combined incidence in the whole series of 72 patients was seventeen ( 23 per cent.).

Electrical abnormalities seem most likely to occur in patients in whom the wrist is involved and the grip strength diminished, but there is no relationship between these findings and occupation, classification of arthritis, functional grade, or any other feature of rheumatoid arthritis. Patients with electrical abnormalities do not differ from patients without them, and the abnormalities are frequently transient.

We wish to thank the Arthritis and Rheumatism Council for generous aid towards this prospective study of early rheumatoid arthritis and our clinical colleagues for their cooperation and active participation in the study as a whole. Our thanks are due to Prof. I. M. Roitt and his staff for the immunological studies and to Dr. P. M. Fullerton who not only gave us facilities for electrodiagnosis but also assisted us with valuable advice and criticism.

\section{Discussion}

DR. V. WRIGHT (Leeds) We have been interested in this whole question of median nerve compression in rheumatoid arthritis and it still intrigues me that there is such a high incidence, particularly in the study of Barnes and Currey (1967) of some 40 per cent. The incidence in 126 patients that we have studied was only about 12 per cent. There are one or two questions I should like to ask:

(1) How reliable did you find the two-point discrimination? We have not found this to be a reliable clinical test and should be interested to know how far apart your points were.

(2) Do you think that you can make an accurate diagnosis on clinical features alone? What are your objective criteria? I have already suggested that the two-point discrimination criterion is not a very reliable one, and neck lesions can produce symptoms very similar to those of the carpal tunnel syndrome.

(3) Have you any patients whose rheumatoid disease first presented with the carpal tunnel syndrome? We have four who started as electrically proven cases of carpal tunnel syndrome and went on to develop rheumatoid arthritis.

DR. CORBETT On the whole we found the two-point discrimination test reasonably reliable, in as much as it correlated very closely with loss of other sensations such as touch. It is very difficult, particularly in examining a manual worker, to know how far the two points should be apart, and it has always been our practice to have them about $0.5 \mathrm{~cm}$. apart or less. The two-point discrimination apparatus is constant for each patient, always staying at the same level. On the basis of fairly long experience, not confined to the patients described above, we feel that it is probably reliable, in as much as the history of nocturnal paraesthesiae is very characteristic and our 
patients respond very well to local injections of hydrocortisone which we prefer as a diagnostic test to the electrical diagnostic test.

Out of a series of 72 cases, two presented with carpal tunnel syndrome.
DR. D. N. GOLDING (Harlow) Did you estimate the duration of action potential of motor conduction? It has been suggested that this sometimes is a more reliable index of median nerve block than the latency.

DR. CORBETT No.

\section{References}

Barnes, C. G., AND CURReY, H. L. F. (1967) Ann. rheum. Dis., 26, 226 (Carpal tunnel syndrome in rheumatoid arthritis).

Brewerton, D. A. (1965) In 'Progress in Clinical Rheumatology', ed. A. St. J. Dixon, p. 56. Churchill, London.

Copeman, W. S. C. (1968) Ann. roy. Coll. Surg. Engl., 43, 274 (Some thoughts on the surgical treatment of rheumatic diseases).

Dawson, G. D. (1956) J. Physiol. (Lond.), 131, 436 (Relative excitability and conduction velocity of sensory and motor nerve fibres in man).

Gilliatt, R. W., AND Sears, T. A. (1958) J. Neurol. Neurosurg. Psychiat., 21, 109 (Sensory action potentials in patients with peripheral nerve lesions).

Pallis, C. A., AND ScotT, J. T. (1965) Brit. med. J., 1, 1141 (Peripheral neuropathy in rheumatoid arthritis).

Polley, H. F., ANd Lipscomb, P. R. (1966) Méd. et Hyg. (Geneve), 24, (No. 731), p. 408 (April 27).

Thomas, P. K., Sears, T. A., and Gilliatt, R. W. (1959) J. Neurol. Neurosurg. Psychiat., 22, 175 (The range of conduction velocity in normal motor nerve fibres to the small muscles of the hand and foot).

\section{RÉSUMÉ}

Le syndrome du canal carpien au début de l'arthrite rhumatoïde

Des 72 malades admis à une étude éventuelle faite au début de l'arthrite rhumatoïde, 36 ont consenti à une enquête électrodiagnostique. Sept anomalies électriques d'importance secondaire ont été trouvées chez quatre malades; deux d'entre eux montraient des signes cliniques du syndrome du canal carpien. De plus, quatre sujets avec diagnostic clinique évident du syndrome du canal carpien donnaient des tests électrodiagnostiques normaux.

L'incidence des anomalies électrodiagnostiques chez les 36 soumis aux tests était 5,5 pour cent; l'incidence du syndrome du canal carpien diagnostiqué cliniquement était 17 pour cent: 6 des 36 malades qui avaient subi des tests électriques, et l'incidence combinée était 23 pour cent : 17 de tous les 72 malades.

Les anomalies électriques semblaient avoir lieu le plus souvent chez les malades qui avaient une affection du poignet et l'étreinte des mains était diminuée, mais il n'y a aucune relation entre ces observations et le métier des malades, la classification de l'arthrite, le degré fonctionnel ou n'importe quel autre signe de l'arthrite rhumatoïde. Les malades avec les anomalies ne diffèrent pas des malades sans anomalies et les anomalies sont fréquemment passagères.

\section{SUMARIO}

Síndrome de túnel carpiano en poliartritis reumatoide incipiente

De 72 pacientes sometidos a un estudio exploratorio de poliartritis reumatoide incipiente, 36 accedieron a participar en una investigación por electrodiagnóstico. Se descubrieron siete anormalidades eléctricas leves en cuartro pacientes, dos de los cuales tenían pruebas clínicas de síndrome de túnel carpiano. Otros cuatro sujetos con diagnosis clínica segura de síndrome de túnel carpiano arrojaron electrodiagnósticos normales.

Así, pues, la incidencia de anormalidades, reveladas por electrodiagnóstico en las 36 personas sometidas a prueba, fue de 5,5 por ciento; la incidencia de síndrome de túnel carpiano diagnosticado clínicamente en los 36 pacientes sometidos a pruebas eléctricas fue de seis (17 por ciento), y la incidencia combinada en toda la serie de 72 pacientes due de diecisiete ( 23 por ciento), Las anormalidades eléctricas parecen ocurrir con mayor probabilidad en pacientes que tienen afectada la muñeca y debilitada la fuerza prensil, pero no existe relación entre estos descubrimientos y la ocupación, clasificación de la artritis, grado funcional o cualquiera otra característica de la poliartritis reumatoide. Los pacientes con anormalidades eléctricas no difieren de los pacientes sin ellas, y las anormalidades son, con frecuencia, transitorias. 